\title{
九州・沖縄地方の学童・生徒体位と同地方住民の栄養 摂取水準の時代的推移
}

$$
\begin{array}{lllllllll}
\text { 中 } & \text { 村 } & & \text { 正* } & \text { 湯 川 } & \text { 幸 } & \text { * } & \text { 森 } & \text { 本 } \text { 和 枝* } \\
\text { 平 } \text { 田 } & \text { 文 } & \text { 夫 } & \text { 池鯉鮒 } & \text { 治 } & \text { 明* } & \text { 池 田 高 士* } \\
\text { 田 } & \text { 原 } & \text { 靖 } & \text { 昭* } & \text { 管 原 } & \text { 正 志* } & \text { 石 原 結 美* }
\end{array}
$$

A comparison between changes in the physical constitution of school children and the average nutritional intake of selected populations in Japan

$$
\begin{aligned}
& \text { Masashi NAKAMURA*, Kouichi YUKAWA*, Kazue MORIMOTO*, } \\
& \text { Fumio HIRATA*, Haruaki CHIRIFU*, Takashi IKEDA*, Yumi ISHIHARA*, } \\
& \text { Yasuaki TABARA* and Masashi SUGAHARA* }
\end{aligned}
$$

At the time before World War Two, the physical constitution of school children (PCSC), i.e., height, weight, girth, etc., in the Kyushu district, (one of the main islands in Japan), was almost the same as that of the national average. After the War, PCSC throughout Japan, continued to improve until recently, as a result of the increases in the standard of living.

However, the mean PCSC of seven prefectures in the Kyushu district have been found to be lower than that of the national average. It was also found that the levels of nutritional intake, which is considered to deeply affect physical growth, have been lower in the Kyushu district than those in the other districts. So, in this study, the annual values of PCSC reported from the Education Ministry and of nutritional intake as calculated from the National Nutrition Survey carried out by the Welfare Ministry, is compared between the Kyushu district, with those of the national average, the Okinawa and Kagoshima prefectures and the Shikoku district.

The results obtained are as follows;

1) The annual average height of school children, aged 15 years, were lower in all the prefectures of the Kyushu district than in the other districts throughout Japan during the years 1964-1976. The average height in the Okinawa prefecture were lower than those in the Kyushu district.

2) When data from the National Nutrition Survey was compared to PCSC, it was found that in 1964 and 1967, both mean values of nutritional intake and PCSC for children, aged 17 years, were lower in the districts of Kyushu and Shikoku, (another main island in Japan that neighbors Kyushu), than those in the other districts.

\footnotetext{
*長崎大学医学部衛生学教室

* Department of Hygiene, University of Nagasaki School of Medicine
} 
3) The results of the Farmer's Nutrition Survey, carried out annually by the Agriculture and Forestry Ministry shows that levels in the Kyushu district were lower than those throughout the whole country. This finding supports the differences in nutritional intake between the Kyushu district and the other districts, as reported in the National Nutrition Survey.

4) The cohort values of height of school children, aged 17 years in the year 1975, were calculated from the annual results of the Education Ministry and compared between the national average, the Okinawa prefecture, and the Kagoshima prefecture, with the lowest PCSC vlaues in the seven prefecture in the Kyushu district. The difference between the Kagoshima prefecture and the national average, and the Okinawa prefecture were already observed at the age of 5-6 years, and continued to the age of 17 years.

5) Annual mean values of heights of children, aged 5 years, were compared between national average and th Kagoshima prefecture. Those in the Kagoshima prefecture showed a trend of approaching the national average as time passed.

The above facts suggest that the difference in PCSC between the Kyushu district and the whole country will decrease and probably disappear in the near future. However, that does not appear to be the case of the Okinawa prefecture.

\section{I 緒言}

戦後一旦低下した生活水準の回復とともに，日 本人の体位の向上はめざましいものがある。しか し，そのなかで九州各県及び沖縄県学童の体位は 最低のグループをつくってきた。体位の地域差を 検討する場合には，身体発育におよぼす環境の要 因のなかでは栄養状態に先ず視点をあわせるべき であろう.

栄養状態が発育に強い影響力をもっていること は，我国が第二次大戦を通じて経験しているとこ ろである．昭和14年頃まで緩やかに上昇していた 学童の体位は, 戦時中および戦後の未曾有の食糧 難により急激に低下した。しかし，昭和 25 年から 30年頃までに回復し，その後体位は専ら向上促進 してきた.この学童の体位の経過は食糧事情およ び国民の経済力に伴う摂取栄養状況の推移とよく 一致している.

ところが近年の学童体位の向上に九州地方の学 童のそれは遅れをとり，その体位は相対的に低い 水準にある.なぜ九州・沖縄地方の学童の体位が 劣っているかを，その背景としての栄養摂取の推
移を検討することによってうかがい知ろうとした.

\section{II 調查方法}

体位としては学校保健統計調査報告毒（文部省 1956〜'76)より身長および体重をとりあげた．沖縄 県を除く九州 7 県別平均值の算術平均をもって九 州地方を代表する平均值とみなした。

栄養摄取状況は国民栄養調査(厚生省1955～～75) および農民栄養統計（農林省1951～’ 70）を中心に 九州・沖縄各県の行政機関や教育研究関係者より 提供された各種栄養調査の成績を用いた。

なお国民栄養調查において地域ブロック別の成 績を出している年次の報告書で，ブロック区分は 次の通りとなっている.

北海道

東北（青森，岩手，宮城，秋田，山形，福島）

関東 I（埼玉，千葉，東京，神奈川）

関東 II（茨城，栃木，群馬，山梨，長野）

北陸（新潟，富山，石川，福井）

東海（岐阜，静岡，愛知，三重）

近畿 I（京都，大阪，兵庫）

近畿 II（奈良，和歌山，滋賀） 
中国（鳥取，島根，岡山，広島，山口）

四国（徳島, 香川, 愛媛, 高知)

北九州（福岡，佐賀，長崎，大分）

南九州（熊本，宮崎，鹿児島）

沖縄

\section{III 成 績}

1.九州・沖縄学童の体位の全国平均との比較 15歳および17歳の生徒について，その身長の全 国平均と，沖縄を除いた九州地区平均值の年次推
移を男子は図 1-1，女子は図 1-2に示した。 両平均値と併せ並べて京都, 福岡, 鹿児島及び沖 縄の各県の值も同図中に示した。ただし17歳值及 び沖縄県值はその戦前の資料が得られなかった.

男子15歳についてみると, 戦前の最高值に達し ていた頃の昭和13年の九州平均値は全国平均値に 近いが, 戦時中, 終戦後の落ちこみの後は, 回復 期，その後の向上期から最近にいたるまで全国平 均值より低位を続けている。

最近全国でトップレベルにある京都は，昭和 23

図 1-1 九州地方の学童の身長（文部省值）

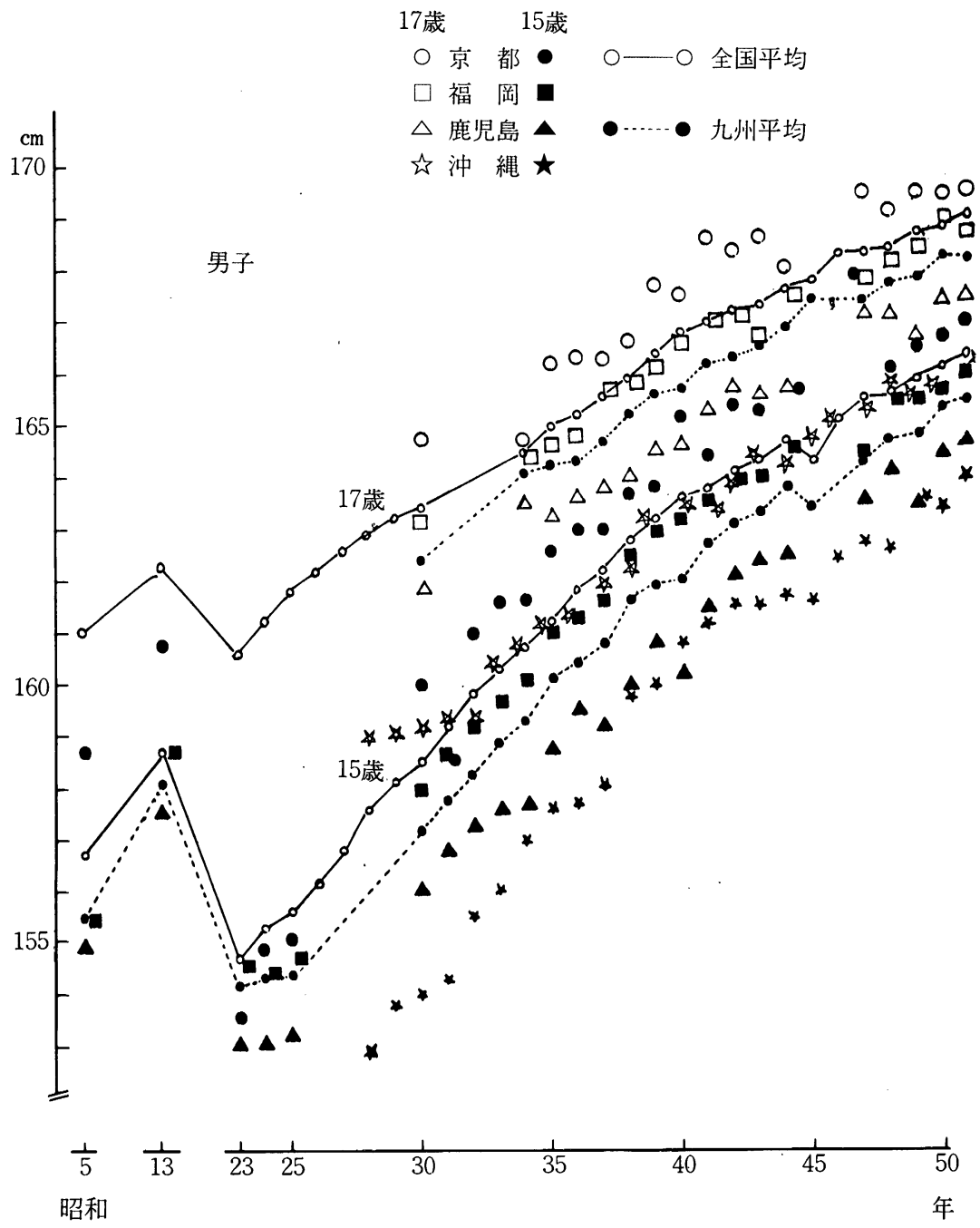


年には九州平均より下まわっているが，すでに昭 和30年值は全国平均を上迴って向上し来たってい る. 一方，九州グループでは最も上位の福岡でも 全国值に近づいてはいるが，わずかに下まわった ま入で昭和51年にいたっている．沖縄は昭和 30 年 には全国値より $4.5 \mathrm{~cm}$ も低く，昭和 51 年でも $2.3 \mathrm{~cm}$ の差があり全国で最下位にある.

17歳でみると九州平均値と全国値との差は，15 歳値に比べて若干少なめであるが15歳と同様に全
期を通じてみとめられる。しかし最近では全国の トップを切って上昇して来た京都值はこのところ 停滞している.

女子(図 1-2)についても男子と同様の傾向で 九州は全国より低いレベルである．特に沖縄県の 劣りは著しい. 17歳の九州平均值は, 昭和 37 年頃 からは15歳の全国值に追いつかれてこれと同レべ ルないしこれより下回る有様である。また沖縄は やはり他県に劣っているが,その17歳值は昭和 37,

図 1-2 九州地方の学童の身長（つづき）

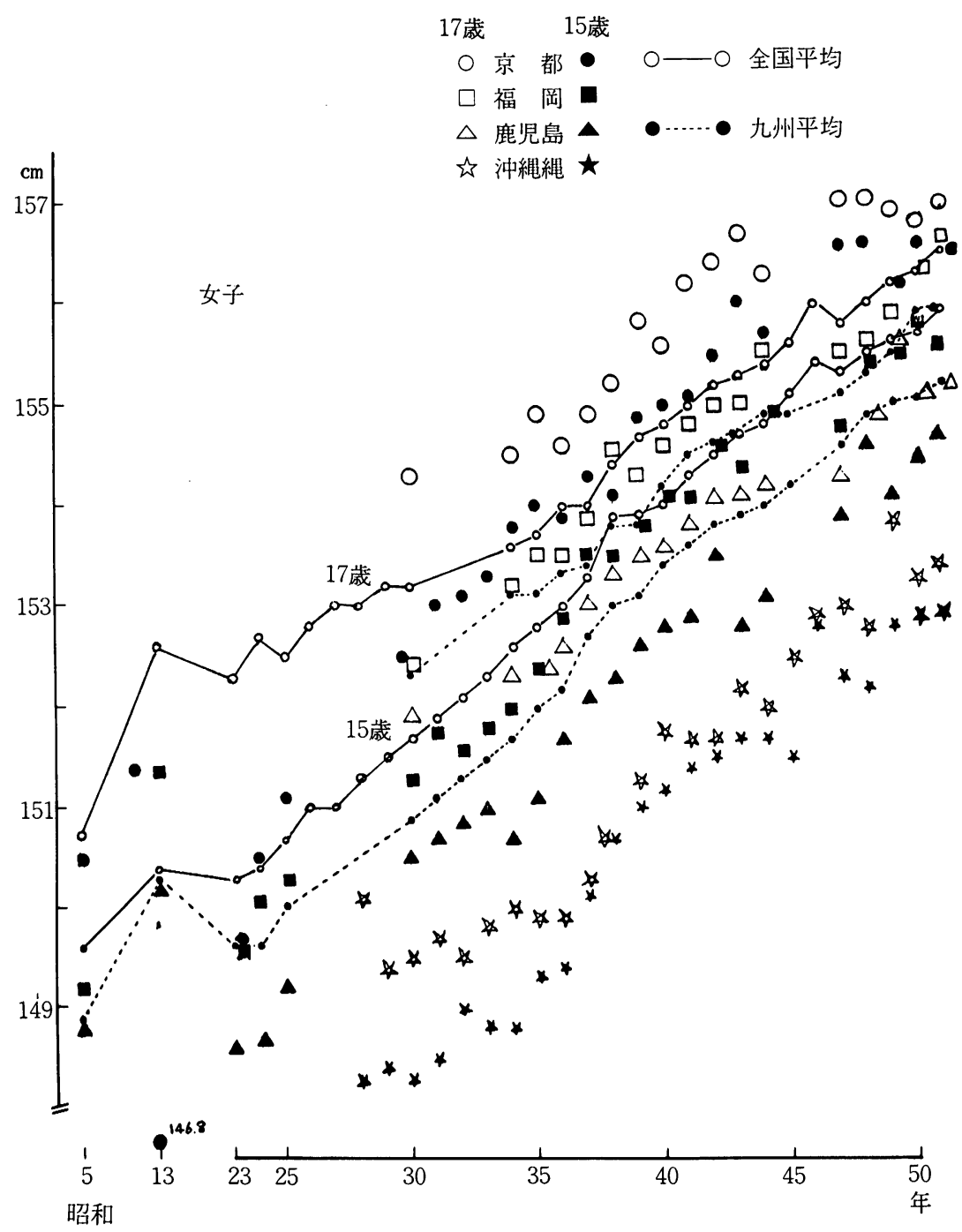


38年の両年では同県の15歳値に追いつかれた形で この両年粎間の身長の差はみとめられず，39年に なって再び年秢差があらわれている．51年以降の 推移がどうなって行くかが興味深い. なお17歳と 15歳の両年粭値間の差は全国・九州の両平均值に おいても38年ころから年次とともに縮まっている. 一方全国のトップレベルを進んでいる京都府の值 は両年柃ともに昭和 47 年頃からその伸びがとまっ た状態を呈しており，これは最近の食を中心とす る生活条件下での日本人の発育の限界が京都府値 のレベルあたりにありそうに思わせる.

ともあれ要するに，全国のトップレベルにある 京都府の身長はもちろん全国平均値に比べて九州 地区の身長はともに戦後快復, 上昇の傾向をとり ながらも終始劣り続けている。この較差が栄養摂 取状態の較差に影響されているのではないかとい うことが当然考えられる．そこで九州・沖縄地方 の栄養摂取水準を全国平均值並びに他地域と比較 してみることにする.

\section{2. 国民栄養の推移と九州・沖縄の栄養摄取水} 準

発育と栄養との関連をみるに当っては，本来発 育期にある者についての栄養摂取状態を検討する のが妥当であろう。しかし年からこの様な広域に わたり両者の関連を直接追求するのに答えれるだ けの資料は先ず得られないので, 次善の策として 国民栄養調査（厚生省）や農民栄養調査（農林省） の成績の公表資料に拠わて可能な限りこの関連を 追求することとした．資料の中の国内地域ブロッ ク別比較成績の 1 人 1 日当り栄養摂取量值から調 査世帯の一構成員である発育期の者の栄養摂取状 態を類推しても大きな誤りはないものと考えて， 以下のような検討をこころみた．

まず戦後に始まる国民栄養調査にみる国民の食 品群別摂取量の推移としては, に代表される戦争直後のいわゆる代用食品類はそ の後急減し, 穀類も一旦増加したが, その後は漸 減傾向にある. 一方, 乳・肉・卵類・果実類は堌 加しことに昭和40年頃から著増した，栄養素別摄 取量でみると, 総体的には戦時中及び戦争直後の
劣悪な状態から昭和 25 年頃までに戦前のレベルま で回復している（食糖需給に関する統計結果（農 林省官房調査課）では 1 人 1 日供給熱量は昭和 13 年で $2,135 \mathrm{Cal}$ であるが, 昭和 29 年頃にはこのレベ ルに到達した)。そして昭和 35 年頃より急上昇して 最近この数年は大体落付いた摂取量を示している. 特に増加してきた栄養素として動物性蛋白, 脂肪, カルシウムおよび $\mathrm{VB}_{1}$ が挙げられる.

この国民栄養調查で地域ブロック別の成績が公 表されたのは昭和 $28,39,42,46,49$, 及び50年 度と数少ないのである，その中の昭和39年の成績 を先ず図 2 に揭げる. (この時までは五つの地域ブ ロックに分けてある), 上段はエネルギーから VC までの各栄養摂取量の全国平均を円で示し, 各地 域の摂取量は全国平均に対する比として多角形で 表わしている．下段には文部省統計から15歳の身 長・体重の府県別平均值を筆者が地域ブロック別 に算術平均し，これを全国平均からの偏差值で示 したものである．四国・九州の体位は男女ともそ の劣勢が目立っている.これと相応して各栄養素 とも円の内側にあって全国平均值より低く，かつ 全地域の中で最低である.この四国・九州値は，こ こに図示してないが昭和28年のものよりも小さく 全国的な栄養摂取レベルの 28 年から 39 年への上昇 に対して四国・九州地域の上昇が少なく, 全国平 均值に比べその劣位を示唆している.

昭和 42 年以降の栄養調查成績の報告では, 全国 を12のブロックに分けており, 図 $3-1,-2$ には 昭和 42 年の成績を掲げる. 栄養摂取レベルと文部 省の体位レベルとが概略平行している様子がうか がわれている．即ち近畿 I（前述の京都府を含む） 関東 I, 東北などでは栄養面も良好であり, 体位 も大きいが, 逆に沖縄, 九州, 四国では両者とも 劣っている. 九州の中でも南九州が特に劣り, 栄 養素では動蛋, 脂肪, カルシウム, VA など, 発育 に関連の深い栄養素の不足が顕著である.ここで 沖縄は昭和 47 年の本土返還後では国民栄養調査の 中に加えられているが，それ以前の昭和42年から 毎年沖縄で独自の住民栄養調査が大きな規模で実 施されているので，その成績を図 3 に並べ示した. 
沖縄地域はその栄養も体位もともに本土各地域よ りも劣っていることがわかる.

図 4-1，-2 は同様に昭和50年の成績である. 昭和 42 年以降の 46 年, 49 年の成績も勘案すると国 民栄養は経年的に全国的に均等化してきており， 同図において四国，九州とも多角形がふくらみ円 周に近接している．特に北九州は殆んど全国平均 なみとなっている，南九州も全国平均に近づいて いるが，沖縄はまだ円周よりかなり落ちこんだ状 態で，栄養の劣りがみられている．体位には九州 地区はなお劣りがあり，ことに沖縄で著しい．

次に同じく国民栄養調査の九州・沖縄各県別の 毎年次の成績を全国平均, ブロック別平均となら ベて，図 5 と 6 に示す。昭和46年以前の沖縄（祌 縄県教育委員会1971）および大分（大分県1972’74)はいずれも県独自で行った県民栄養調査の成 績である。
熱量(㘡 5-1)は各県でばらついているので明 瞭な傾向はつかみ難いが，地域別には九州地区は や，低めに推移しているようであり，沖縄はさら に低い. 動物性蛋白は昭和45年まではおしなべて 長崎が他地方に比べて高いが，これは魚介類の摂 取が多いためと思われている(図 6-2 参照)。し かし九州全体としてはや、低めである．次に図 5 - 2 に掲げた脂肪の摂取量では，九州各県の值は 昭和30年以降は全国平均值に比べて低レベルであ るが最近では全国平均に近づいている．沖縄の脂 肪摂取量は多い。カルシウム摂取量では九州各県 は全国平均なみで排移しているが，沖縄はかなり 低い.

以上を総体的にみて, 九州各県はいくつかの栄 養素において全国平均摄取量の遂次的上昇に対し て遅れて推移しているが最近では殆んどの栄養素 がほぼ全国平均に到達したとみなされる。しかし

図2 昭和39年の地域ブロック別各栄養摂取量及び体位の全国平均值との比較 昭和39年 国民栄養調査（们は全国平均）

$\begin{array}{llll}\text { 北海道 } & \text { 関 東 } & \text { 東 海 } & \text { 近畿. 中国 } \\ \text { 東 北国· 九州 }\end{array}$

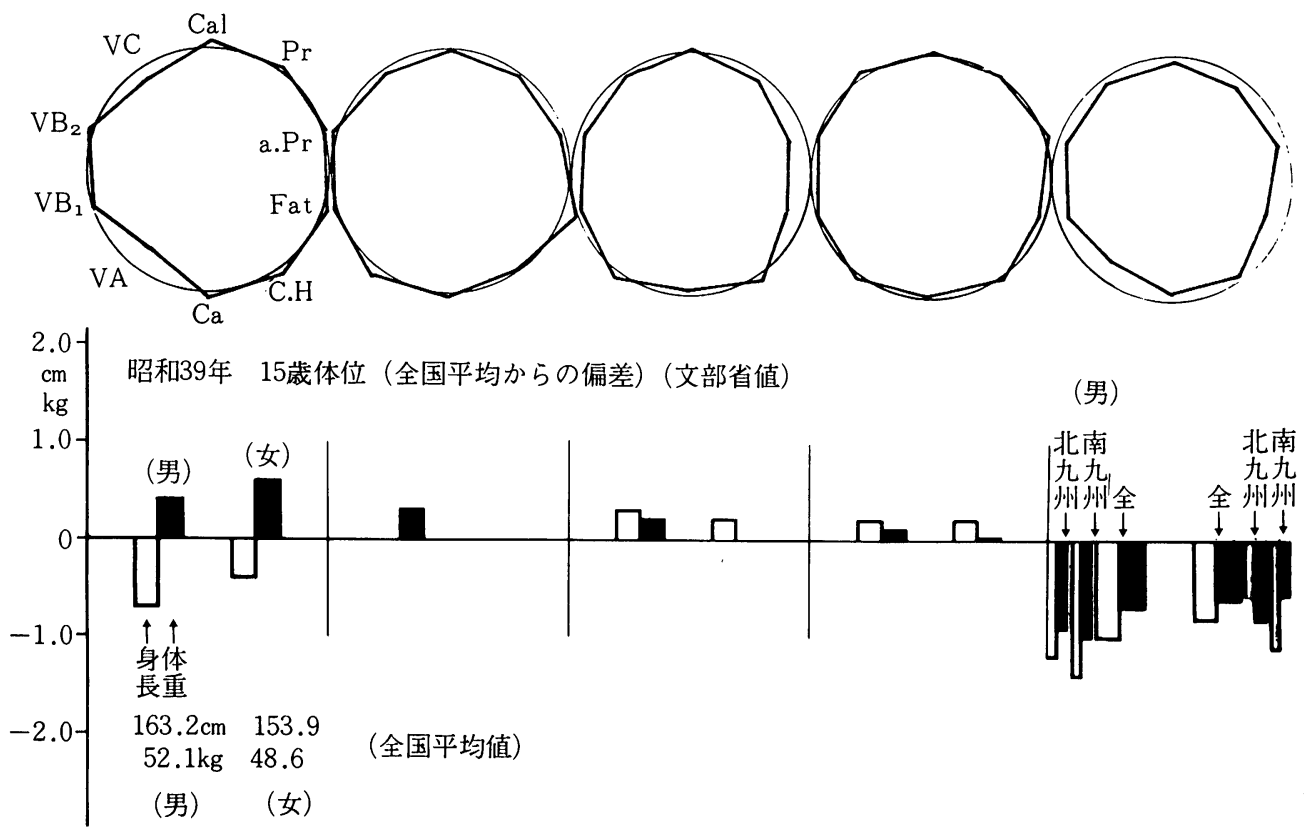


沖縄はまだ相当低いレベルにあり，図に掲げた以 外の栄養素では糖質, 蛋白質, $\mathrm{VB}_{2}$ も低かった.

図 6-1，6-2 は同様に九州各県の国民栄養 調査による食品群別摂取量である. 全国平均に比 ベ各県とも肉, 卵, 乳, 油脂, 緑黄色野菜類が少 く，特に乳類の摂取量が劣っているが，最近では かなり増加して全国平均なみとなっている．沖縄 では肉, 油脂, 緑黄野菜類が多いが卵, 魚介類は 九州各県より少ない

以上のことより九州地方の栄養摂取水準の概要 として, 昭和30年頃からの日本人の食生活条件の 好転に伴う栄養摂取量の上昇に比べて九州の上昇 は小さく昭和40年頃に最も格差が大きくなってき たが，最近では全国平均の水準に近づいてきたと 云える. また沖縄においても食生活の向上は著し ものがあるが，全国平均からみればまだ低い水準 に止まっていると云える.

\section{3. 九州地方の農民栄養の水準}

農林省が行っている農民栄養統計では, 農家経 済調査の中で毎月の購入食糧品と自家生産物の自 家消費量を対象農家に記入させ，その年間の消費 量をつみ上げて栄養摂取量を算出している。この 全国平均と九州地区，近畿地区の成績を国民栄養 調査の全国平均值と共に図 $7-1,7-2$ に示す. この農林・厚生両省の調查はその方法が異なると いう問題があるが，一応一括して比較検討する.

熱量だけは農民栄養平均が国民栄養平均より高 く推移しており， かつ前者は昭和26年から36年へ と一旦低下の傾向をとっているのが特徴的である. 次に他の栄養素は熱量とは逆に農民栄養値が低く 特に動物性蛋白及び脂肪が低い，この傾向は国民 栄養調査一般に見られる農家世帯と非農家世帯の 成績の傾向とも一致している.

農民栄養の地区別の資料は昭和 45 年までしか示

図 3-1 昭和42年の地域ブロック別各栄養摂取量及び体位の全国平均值との比較

昭和 42 年 国民栄養調查（円は全国平均）

北海道 東北

関東 I

関東 II

北陸
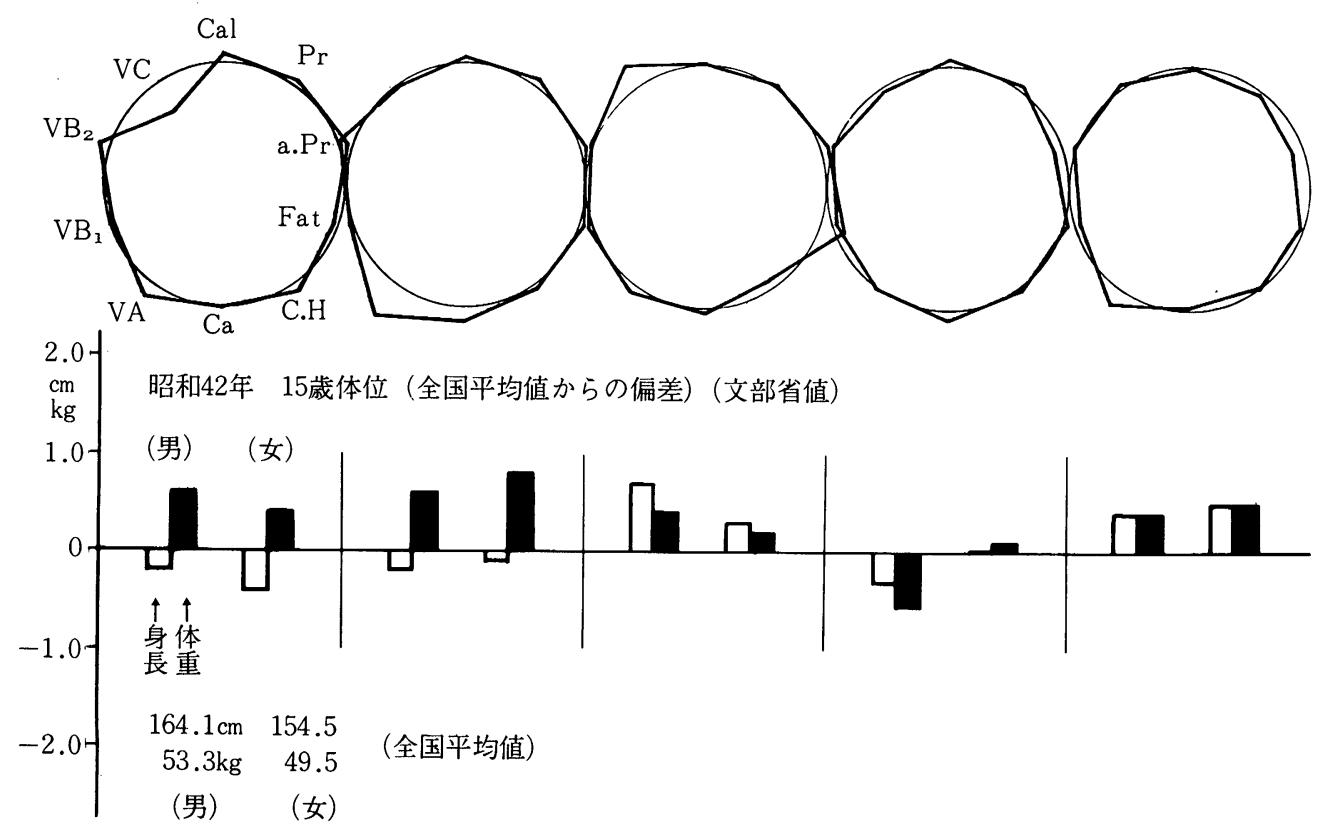
してないが，九州地区を近畿地区と比較すると， 熱量, 動物性蛋白, カルシウム, それにビタミン 類が近畿地方に比べて少ない. 昭和30年代前半で

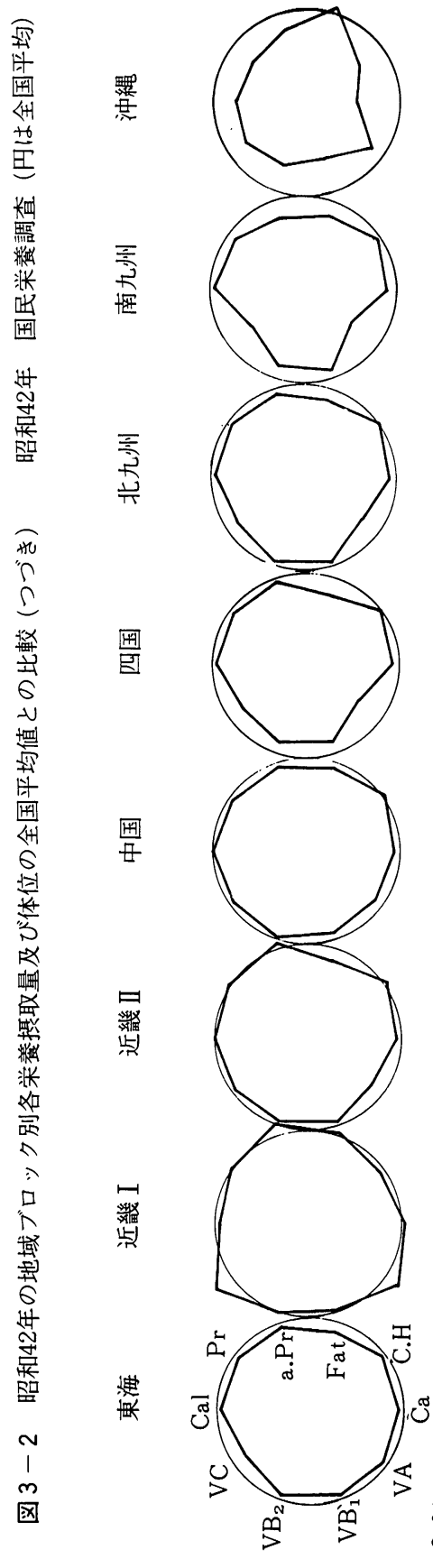

は差が少なく，昭和35年頃から差が開いている. 農家に限っても九州地方ではその食事の改善が他 地域に比べ遅れていることがいえる.

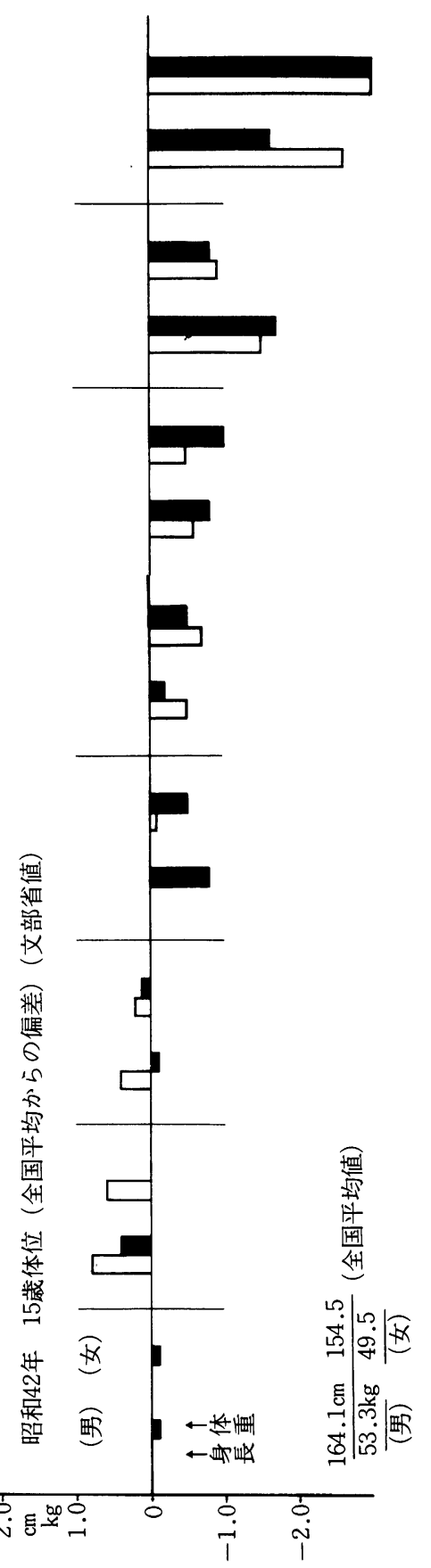


4. 九州, 沖縄地方の体位のコホートについて

これまで九州，沖縄地方の学童の体位水準を 15 歳及び17歳で検討してきた。ここで昭和 50 年に 17 歳にある者について年度をさかのぼって 3 歳の時 からの身長をとってみた。これは即ち昭和33年出 生者の身長の発育線のコホート值であり，図 8 に 示す. 男女とも 5 ～6歳から地域較差があらわれ 始め以降全年齢を通じて鹿児島, 沖縄は全国平均 及び京都より低值を示しており，特に思春期の成 長促進期に差が大きくなり, 高校生の時期にはい くぶん差が縮まるがなお劣勢が続いている. 成長 速度の大きい時期に, 児童の発育が環境要因（本 論では栄養状態を主要因とみなして検討している のであるが）の違いによって影響を受けている様 子がうかがえる.

そこで発育の盛んな幼児の体位では, 九州, 沖 縄地方の栄養状態が改善されてきた最近当地方の 15歳や17歳よりも劣勢の挽回か顕著に現われてい ることが想像される.そこで学校保健統計でとら
れている最年少 5 歳児の年次推移を図 9 に示した (沖縄は昭和 47 年からしか資料を得られなかった). 福岡県は別として九州平均は男女とも昭和 30 年代 ですでに全国平均より $1 \mathrm{~cm}$ 余りの低值を示してい る.しかし最近45年頃からは15歳，17歳の場合よ りも一層全国平均に近づいており，特に男子でそ れが顕著である。また目立つのは鹿児島男子が昭 和51年では全国平均よりも，かつ京都よりも高值 になっている事である．52年以降の推移をなお検 討しないで速断は出来ないが50年代の幼児が少青 年に成長する近い状来には九州地方の子供の体位 は総体的に全国平均なみになってくることがある 程度期待されよう。

\section{IV 考察}

九州地方の学童の体位の低位と栄養の問題につ いては, 昭和34年に藤本 (1966) が検討しているが 当時の九州人の栄養摂取状態には多くの欠陥が認 められ，それが発育期の体位の唄弱さを招いてい

図 4-1 昭和50年の地域ブロック別各栄養摂取量及び体位の全国平均値との比較 昭和 50 年 国民栄養調査（円は全国平均）

北海道東北関東 I 関東 II 北陸
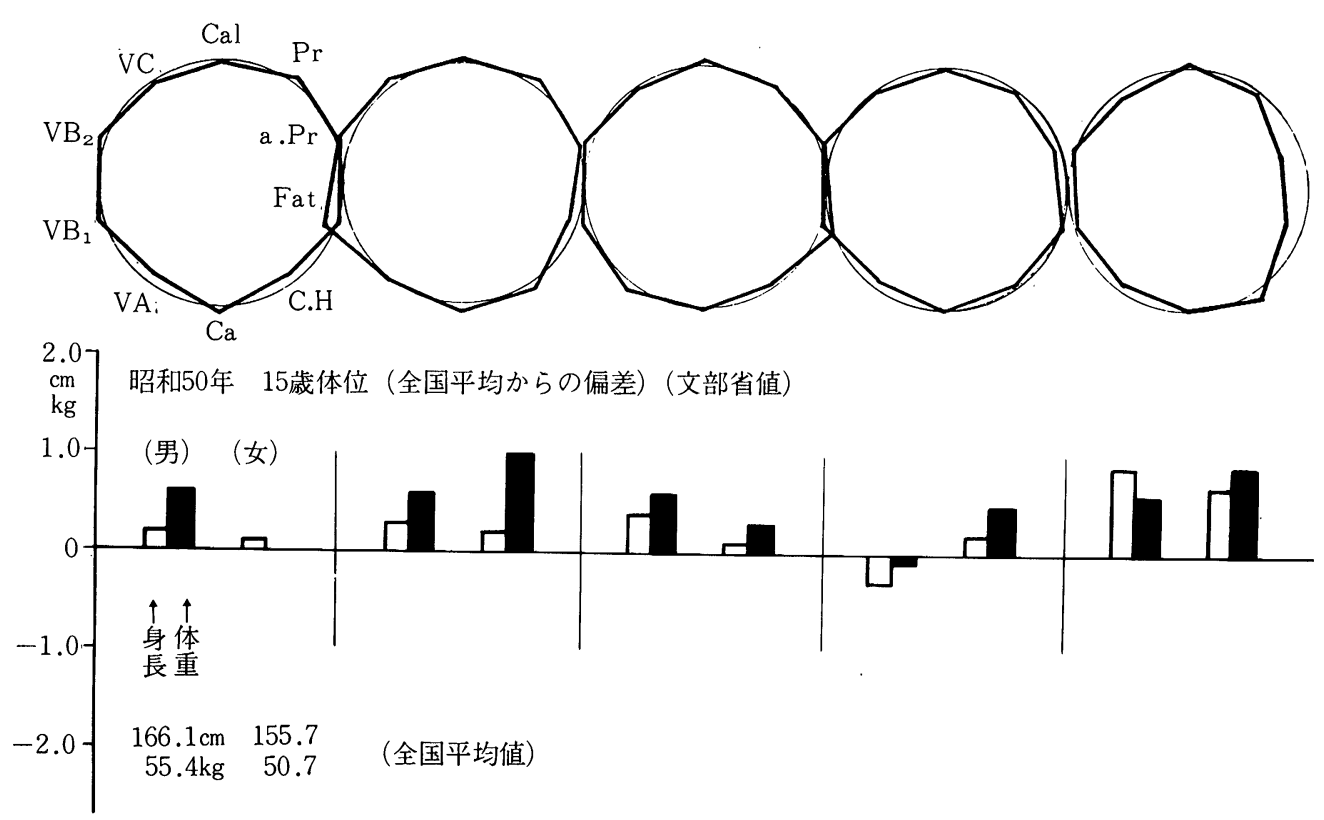
る主因と考察している．また蛋白資源と野菜，果 物などのビタミン，無機質資源の生産が極めて低 く，ある程度発育の不振に結びつくことを指摘し

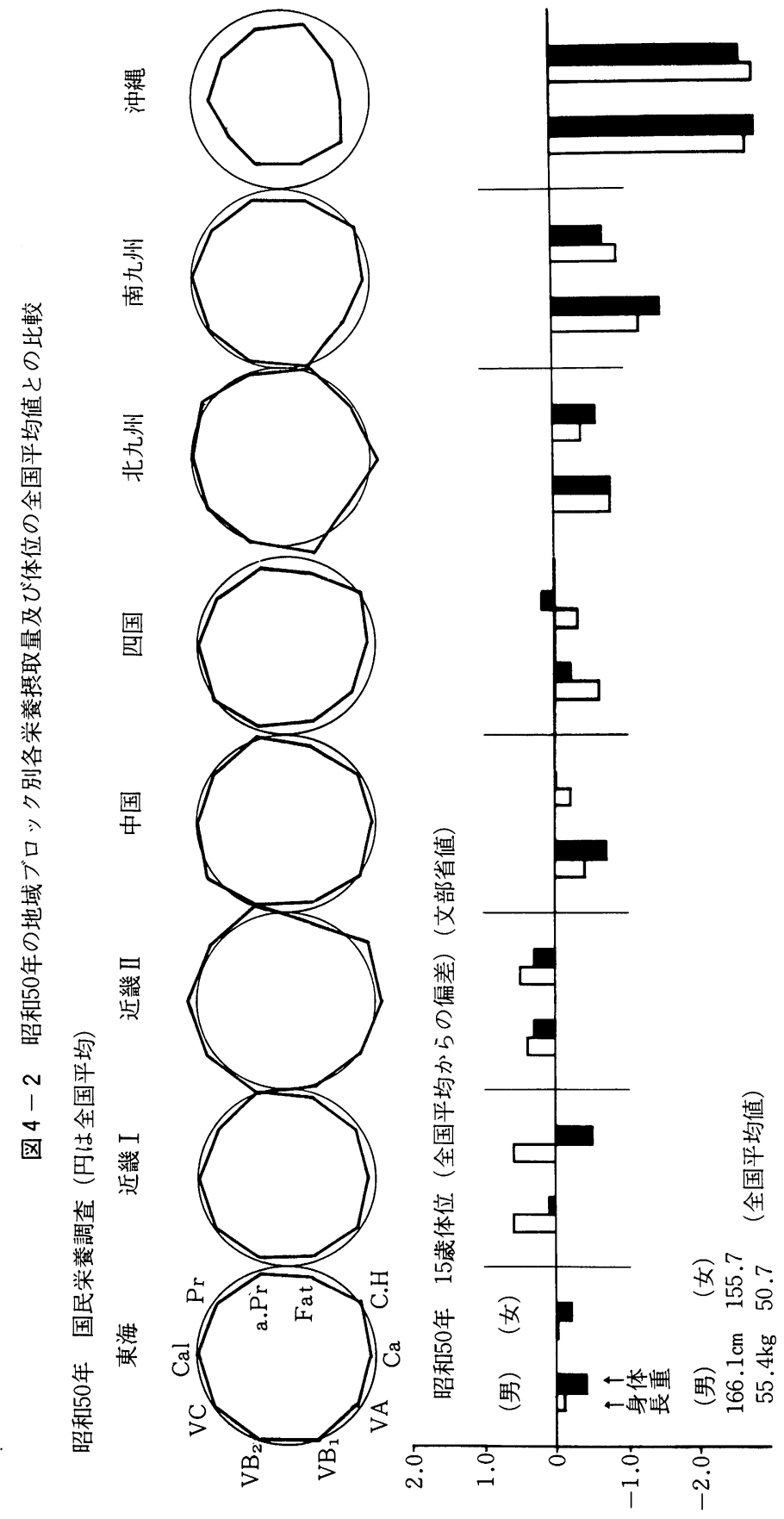

ている．本研究で昭和 42 年でも九州人のこれらの 栄養素の不足がみられたが昭和50年には殆んど全 国平均に近づいている. また学童の体位も最近で 
は全国值との差が縮小してきている．学校保健統 計調査報告によると，5ヶ年毎の全国平均身長， 体重の発育量の差は昭和35 40年の 5 年が最高で 最近年度の体位の伸びは鈍化傾向を示している。 一方身長の最高県と最低県との差は男女とも14歳 までは各年鮯とも昭和 37 年以降年々小さくなって きている. またへき地の学童の身長, 体重は他地 域学童のそれよりも劣っているが，その差は昭和 37，38年をピークにその後漸減しているという.
これらは全国的な生活水準の向上と共に，発育促 進現象と体格の大型化が漸次地方にも波及して全 国的傾向を示し，発育の地域差の縮小，平準化が 促進されていることを示唆するものであろう.

最近でこそ九州地方の 5 歳児の身長は全国平均 に近づいているものの，15歳，17歳児で末だ全国 平均よりや、劣りがある.これには上記コホート 成績からみて彼らがすでに 5 歳期から全国平均と の格差をつけられていたという背景がある.ここ

図 5-1 九州地方の栄養摂取量（1 人 1 日当り）（国民栄養調査）

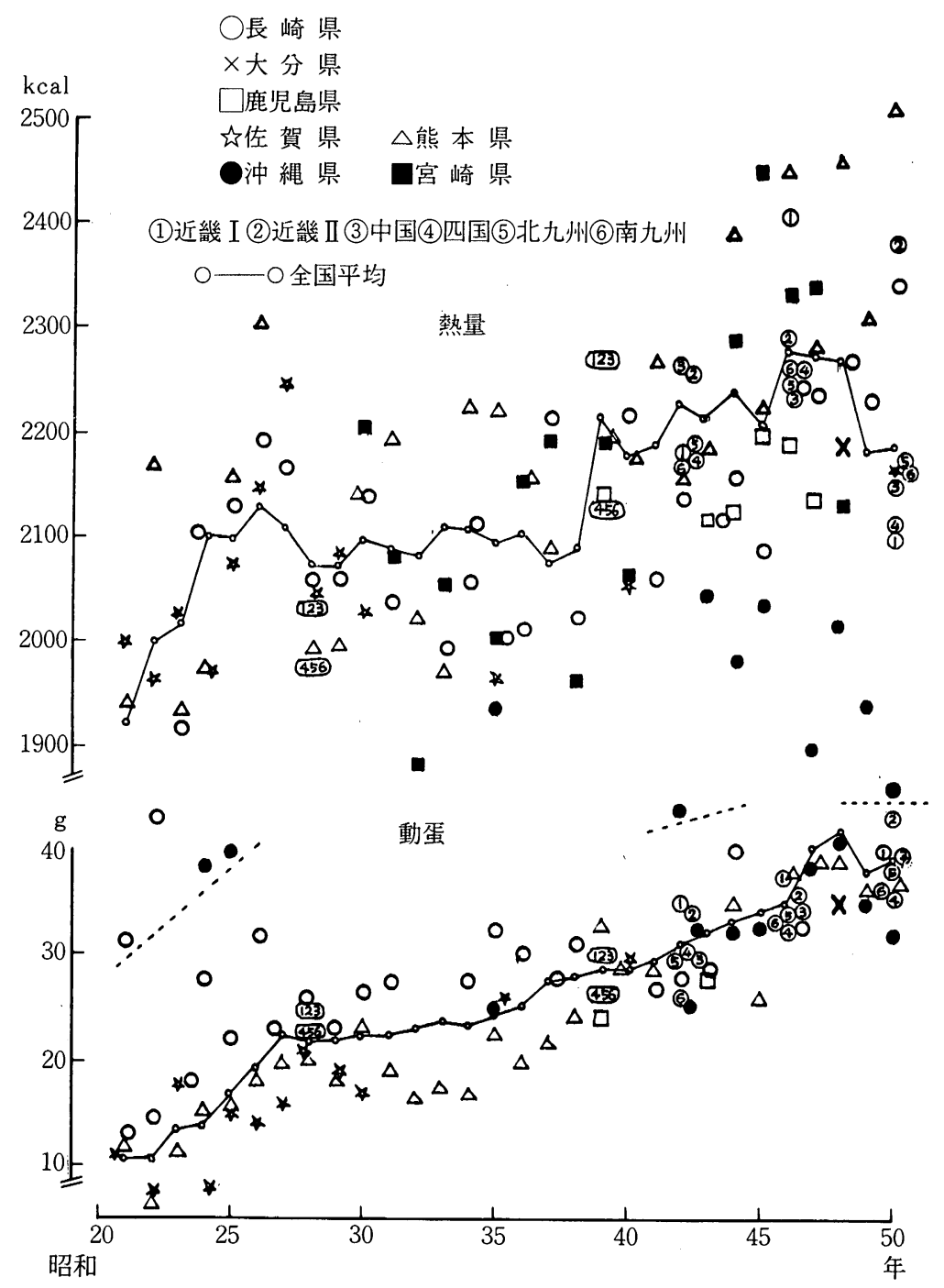


で出生時の体位を考按するに，華表ら（1977）は出 生時体重平均值に明瞭な地域差が存在すること, またその程度は平均值の水準が上昇するにしたが って次第に縮少していることを認めている．その 成績で九州地方の体重は全国では中位の上のとこ ろを推移しており，けっして低位ではないのであ る：したがって 5 墄以降の九州学童の体位が全国 平均より低い值を続けてきた原因は, 幼児・学童 期の栄養水準の対全国平均劣勢にあろうと想像さ
れる，小屋敷ら（1977）は鹿児島県の出生児， 3 歳 児の体位を全国と比較し，出生時の体重は全国よ り有意に上まわっているが，その身長は男子では 3 歳以前から，女子では 3 歳後期までに鹿児島県 が低くなっており，また体重は男女児とも 3 歳前 期までは全国を上まわっているが，その後低くな つていると報告している，離乳食，幼児食からす でに劣りがあり，それが幼児の体位の劣勢につな がり，学童期では家庭での栄意不足をカバーする

図 5-2 九州地方の栄養摂取量（1 人 1 日当り）（国民栄養調査）
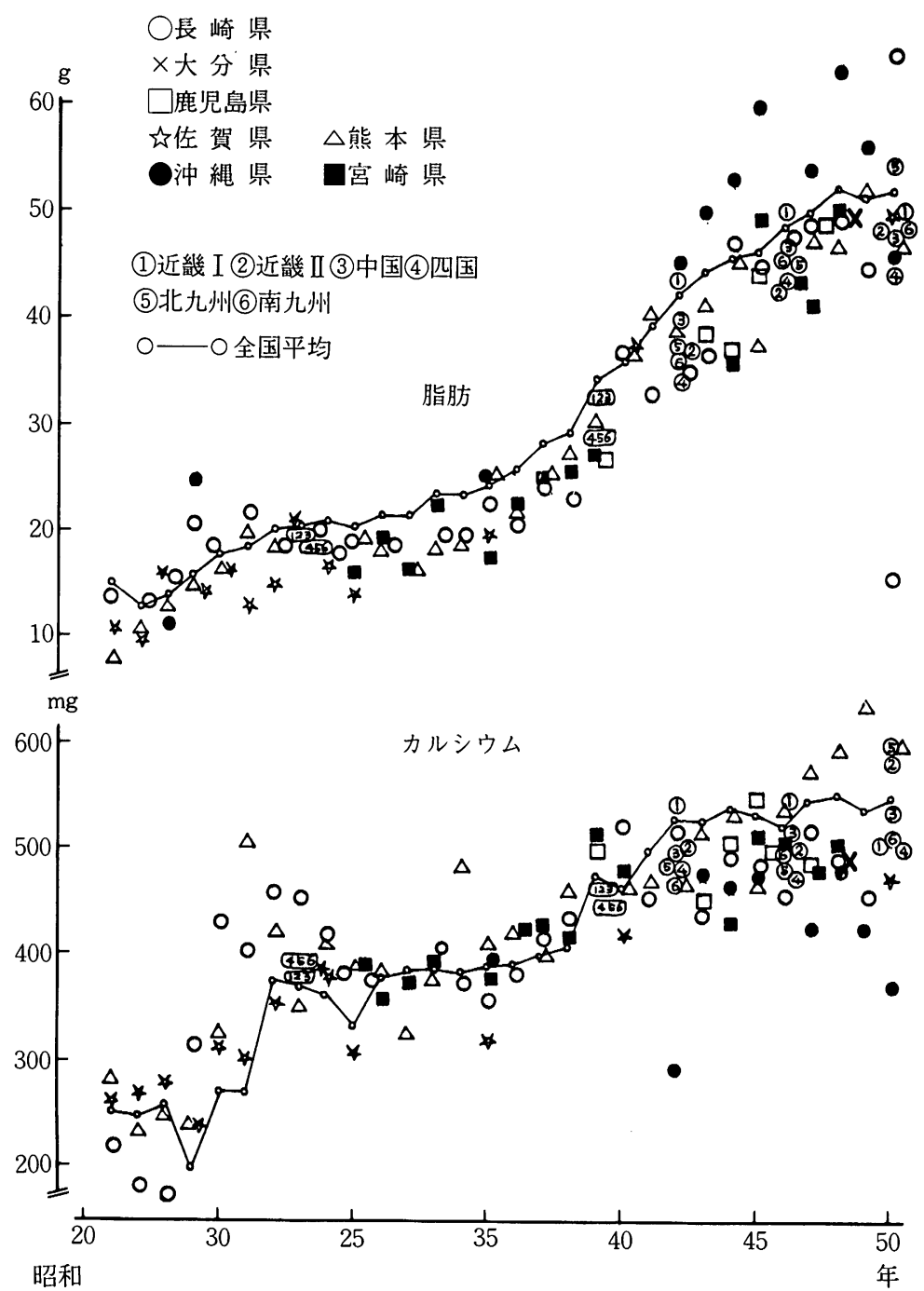
意味で学校給食の意義は大きいが, 体位の劣勢を 挽回するにはいたらず九州学童の体位は低位を続 けてきたのであろう.

また九州の国民栄養調査や各種栄養調査の成績 を都市部，郡部及び島村部と分けてみると，都市 部がよく, 郡部, 島村の順に悪くなっている。こ
のことは，九州地方の中でも特に離島を多くもつ 鹿児県と長崎県や, 山間へき地の多い宮崎県の学 童の県別平均体位が低いことに影響していると思 われる.

いまよりさらに発育期における栄養特に離乳食 幼児食についての関心を高め, 努力していくこと,

図 6-1 九州地方の食品群別摂取量 (1 日 1 人当り)

（国民栄養調查）
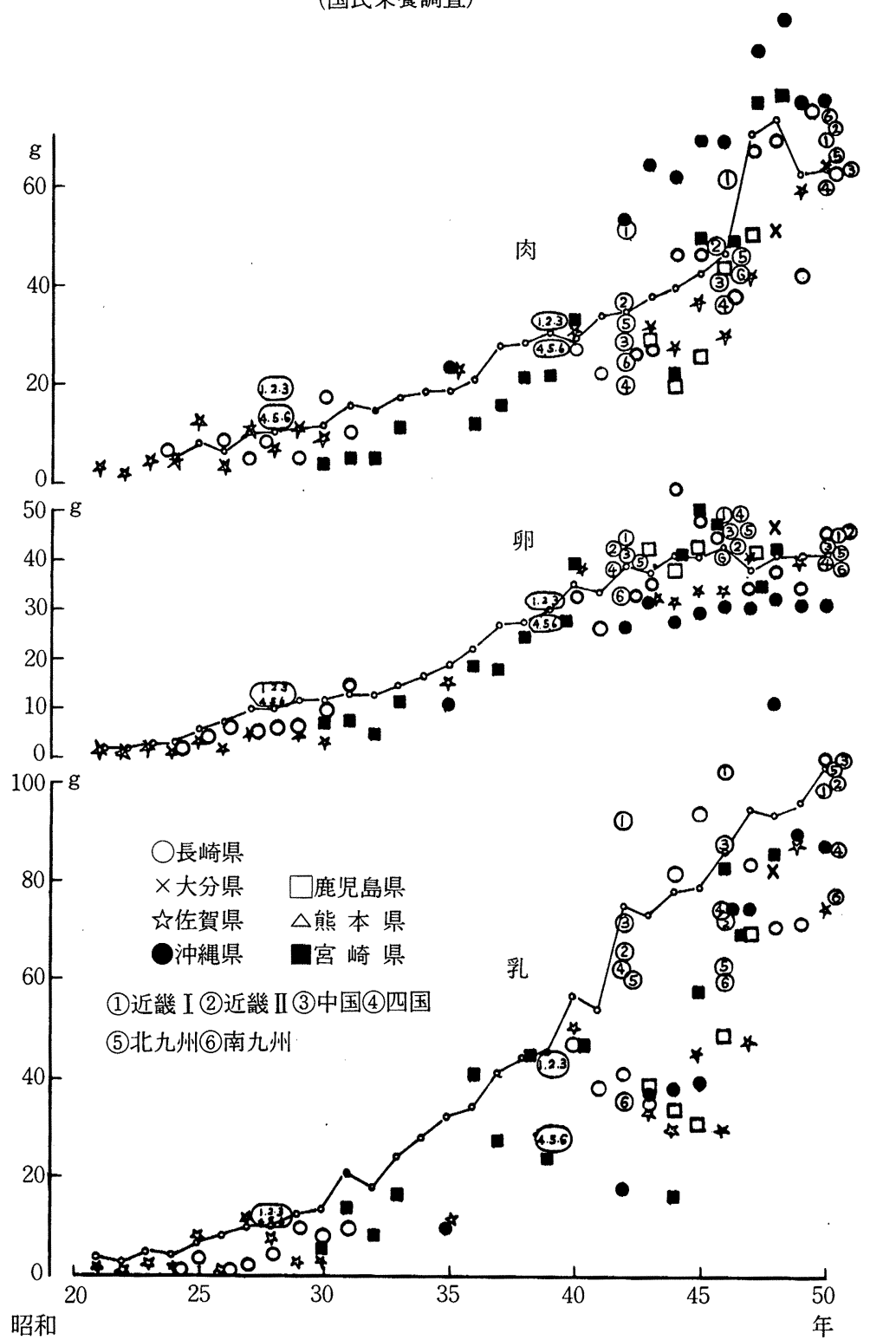
また地域別栄養水準の格差を縮めていく，つまり 農山村や島村の学童の体位を向上させることが, 九州・沖縄全体の体位の向上につながり全国なみ の体位に近づく方策であろう。

\section{$\mathrm{V}$ 総括}

文部省の学校保健統計調査報告からみて, 近年 の学童生徒の体位の向上はめざましいものがある
なかで九州及び沖縄各県の学童の体位は全国の中 で最低のグループをつくってきた。定説視された 体位と栄養摂取水準との密接な関係からみて，九 州・沖縄地方の栄養摂取水準が他の地方と比べて 劣っていることが想像される.

そこで九州・沖縄地方の学童の体位(文部省值) と同地方の栄養水準（厚生省国民栄養調査値その 他）の年次的推移を全国平均或いは体位の高い地

図 6-2 九州地方の食品群別摂取量（1日 1 人当り）（国民栄養調査）

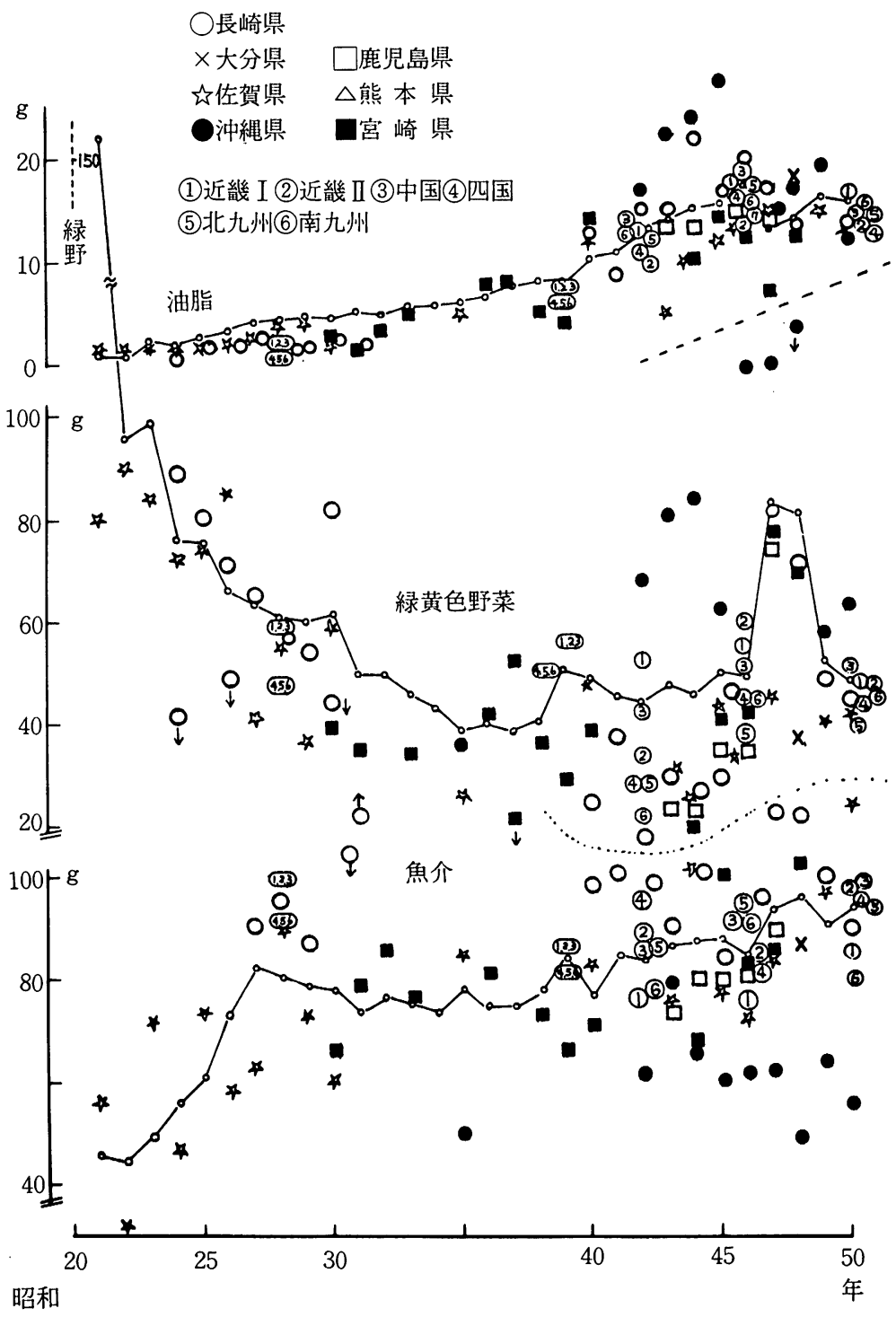


区と比較検討した。

1 ） 15歳の身長についての九州平均值は, 男女 とも戦前の昭和13年には全国平均値に近いが, 戦 争による落ちこみの後は最近にいたるまで全国平 均值より低位を続けている．沖縄は九州各県より もさらに低値で推移し，特に女子でそれが著しい．

2 ) 国民栄養調査の地域ブロック別の成績と 15 歳の身長・体重のブロック別平均值（所属する各
府県別平均值の算術平均）とを対応してみると， 昭和39年および昭和42年の成績では, 近畿,関東, 東北方面に比べて九州・四国は栄養摂取水準, 体 位ともに劣っており, 昭和 42 年の沖縄はさらに劣 りが著しい. 昭和50年の成績では栄養は全国的に 均等化して九州も全国平均に近づいているが, 沖 縄はまだかなり劣る。しかし体位にはなお九州・ 沖縄ともに全国值からの劣りが残っている.

図 7-1 農民栄養調査と国民栄養調査（1 人 1 日当り）
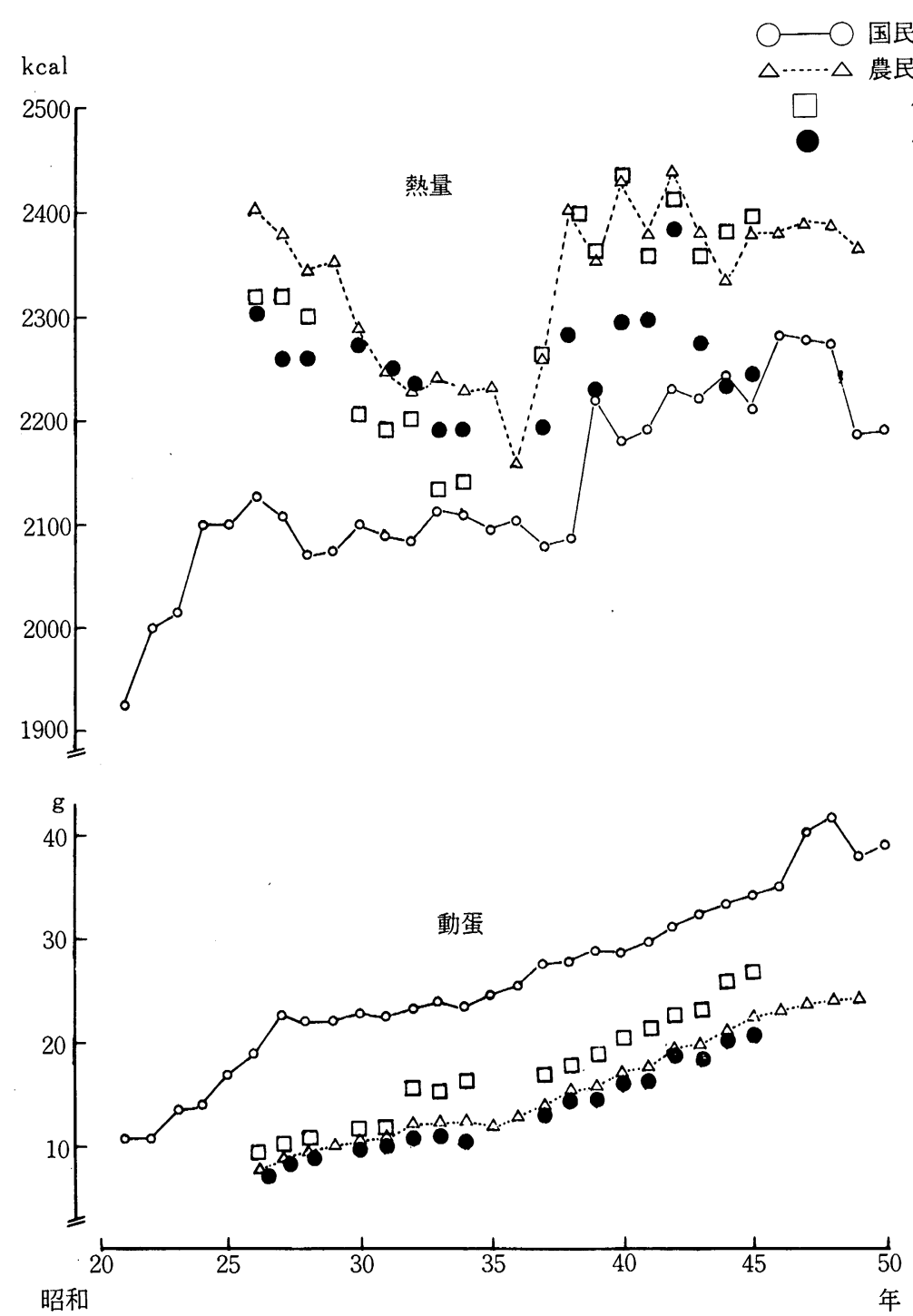
3 ）別に九州・沖縄各県別の毎年次の国民栄盖 調查ないし県独自の県民成績を各県当局ないし個 人の好意で入手し集計した。その結果では昭和 30 年頃からの全国平均栄養摂取量の上昇に比べて九 州諸県の上昇は小さく昭和 40 年頃に最も格差が大 きくなっていたが, 最近では全国平均に近づいて いる．沖縄も栄養摂取量の向上は著しいが，全国 平均からみるとまだ低い水準にある.

4 ）農民栄養統計からみた九州地方の農家世帯 の栄養をその全国平均及び近畿地区と比較すると 昭和30年代前半では差が小さいが昭和35年頃から 九州地区が劣っている．農家に限っても九州地方
では食事の改善が他地方に比べて遅れているといえる.

5 ) 昭和 50 年に17歳にある者について，年度を さかのぼり 3 歳の時からの身長を追跡した結果, 鹿児島, 沖縄は男女とも 5,6 歳から全国平均及 び京都より低値になり始め, 特に思春期に差が大 きくなり高校生で差が縮まるが，なお劣勢が続い ている.

6 ) 文部省統計の最幼年 5 歳児の身長の年次推 移をみると, 九州平均は最近では15歳, 17歳の場 合よりもよりよく全国平均に近づいている.

7 ）発育期における栄益とくに離乳食, 幼児食 についての改善をいまより一層すすめ，また農山

図 7-2 農民栄養調査（1 人 1 日当り）
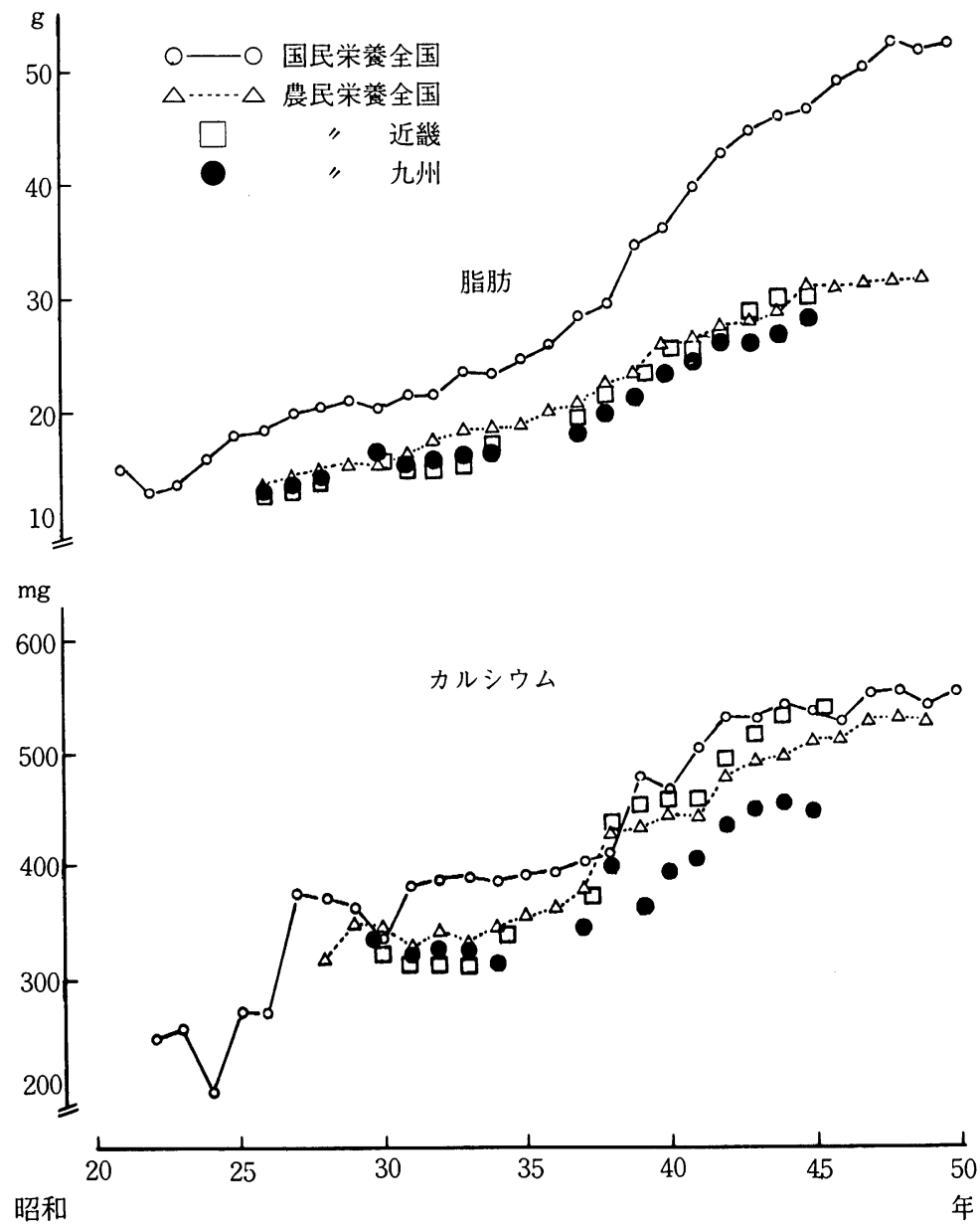
村や島村の学童の体位の向上に努め地域，業態間 の格差を縮めていくことが，九州，沖縄全体の体 位の向上につながる方策であろう。

本研究は, 九州・沖縄を中心とする各種の行政, 教 育関係の専門家や研究者に文書等でお願して提供いた だいたその貴重な調査・研究資料を我々の手元で集計 して出来たものである（この成果の概要は昭和 52 年 4 月の人類動態学研究会で報告した).その際に種々の御 教示や連絡の労をお取りいただき, 資料の集めと提供 をいただいた諸機関や諸士に対し，その御名を下記に つらねて慈にあらためて深甚の謝意を表します。なお 列記の順は不同で，また所属・職名などは昭和 52 年 2 月〜 3 月頃当方からのお願いに応じていただいた当時 のままとさせていただきます。

長崎県庁保健予防課及び飛永季子栄養士, 長崎県立 女子短大赤星千寿教授, 活水女子短大中里富美子助教 授，関夕マノ講師。

佐賀県庁保健予防課江島順子栄養士。

福岡県庁及び同公衆衛生課波多江ヒサ子栄養士，九
大医学部二内尾前照雄教授, 中村学園大山内須美子, 松崎ナツその他諸姉, 久留米信愛女学院本田テル子, 権藤美和子両氏, 久留米大学医学部内科三木村登教授 同中山裕熙氏.

熊本県庁および熊本大学医学部, 公衆衛生二塚信助 教授, 県立熊本女子大安武律助教授.

大分県庁および安東英子栄養士.

宮崎県庁保健予防課，および黒田律子栄養士.

鹿児島県衛生部, 鹿児島純心女子短大若原延子その 他諸姉, 鹿児島女子短大小屋敷武彦その他諸氏, 鹿大 附属病院立川俱子栄養士。

沖縄県琉球大学尚弘子教授, 伊波茂雄県環境保健部 長以下部内諸士, 県教育庁新垣博保健体育課長, 同吉 浜ヒロ子指導主事.

愛媛県聖カタリナ女子短大漢那朝詳教授（前任地長 崎県庁時代からの長年の長崎県下栄養調查資料を総括 していただいた).

文部省（学校保健統計調査資料について）.

厚生省公衆衛生局栄義課竹村宏之氏と柳橋次雄氏.

図 8 昭和 50 年・17歳の身長の発育 (Cohort)

(文部省値)

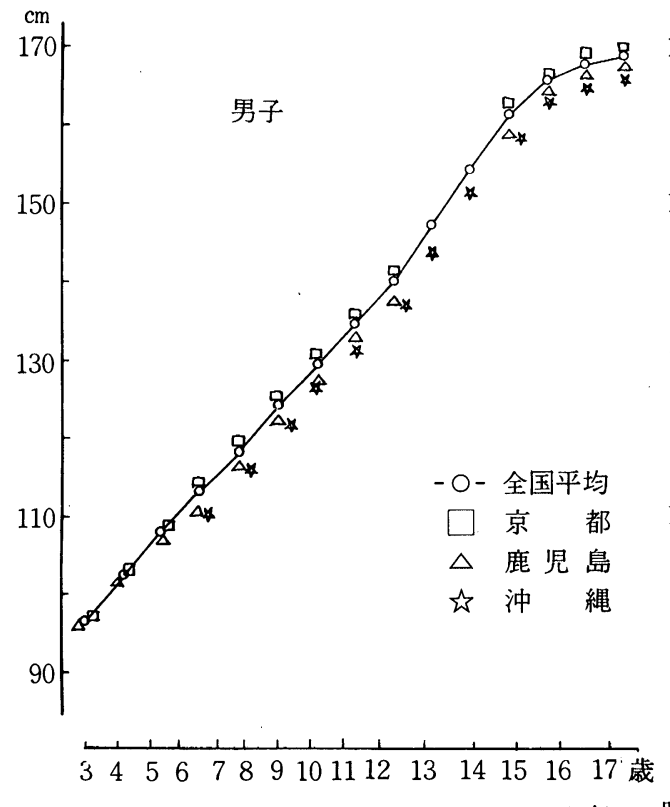

昭和 36

40

45

50

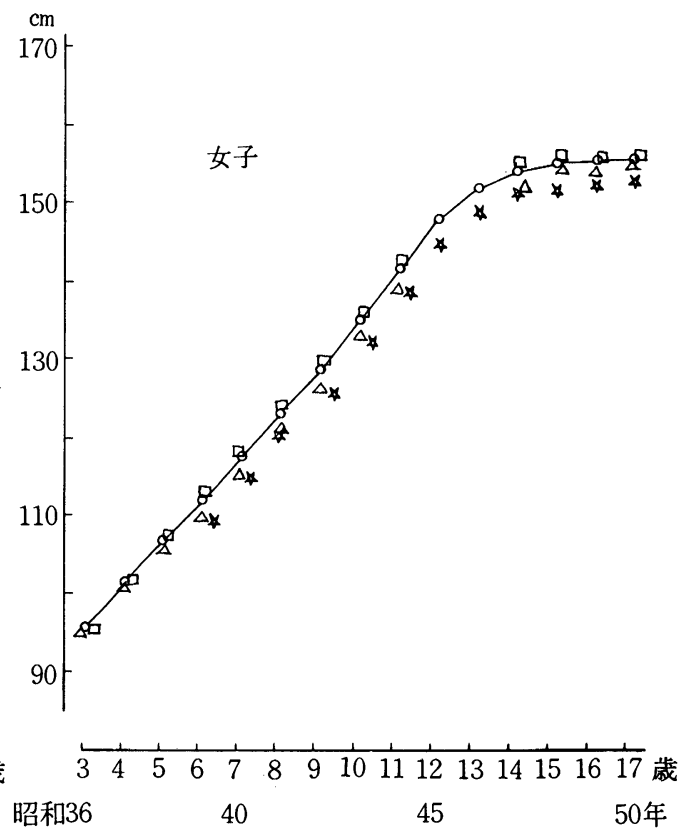


図 9 九州地方の 5 歳児の身長（文部省値）

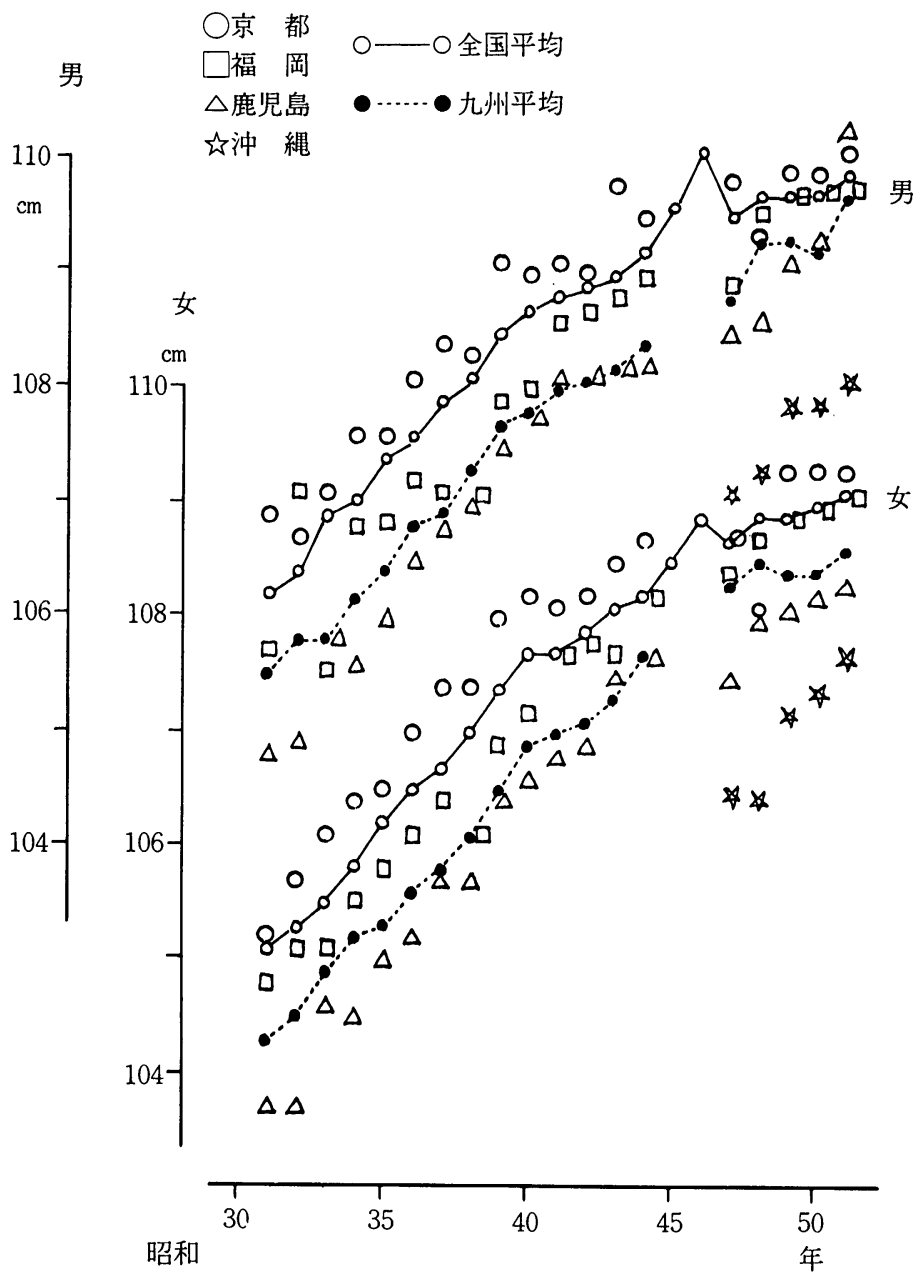

\section{文献}

藤本董喜（1966）：九州地方における食糧と栄養 の問題，民族衛生，26(6)，512-524

華表宏有（1977）：わが国の平均出生時体重の年 次推移 (県および地方別, 単産・複産合計), 日 衛誌, 32( 4)，543-555

小屋敷武彦, 他 (1977)：鹿児島県の学童生徒の 体位はなぜ低いか，鹿児島女子短大紀要，12， $112-118$

㫗生省公衆衛生局栄養課（1955～1975）：国民栄 養の現状，第 1 出版
文部省（1956～1976）：学校保健統計調査報告書 大藏省印刷局

農林省農林経済局統計調査部（1951～1970）：農 民栄養統計，農林統計協会

農林大臣官房調査課編（1976）：食糧需要に関す る基礎統計，農林統計協会

沖縄教育委員会（1971）：学校保健統計調査報告 書, 文京局指導部保健体育課

大分県 (1972 1974): 大分県民栄養調査, 大分県 琉球政府厚生局予防課（1968～1970）：沖縄住民 栄養調査結果表，琉球政府厚生局予防課

(受稿 1981.5.2) 